\title{
The effect of e-learning media application using problem based learning models to activities and results of student learning in salt hydrolysis subject
}

\author{
Nisa Humairah ${ }^{1,2^{*}}$, Marini Damanik $^{2}$, Eddyanto ${ }^{2}$ \\ 'Sekolah Menengah Atas Islam Terpadu Jabal Noor, Medan 2035l, Indonesia \\ ${ }^{2}$ Department of Chemistry, Universitas Negeri Medan, Medan 20221, Indonesia
}

\begin{abstract}
:
This study purpose to determine the improvement of chemical learning outcomes and student learning activities that used e-learning media with problem based learning models on the subject of salt hydrolysis. The design was used One Group Pretest and Postest. The instrument used two domains, namely cognitive and affective. Hypothesis testing is carried out using the two-part of t-test. The hypothesis's test of student learning outcomes obtained $t_{\text {count }}=29.5$ while $t_{\text {table }}=2.03$ for $\alpha=0.05$ and $\mathrm{db}$ $=34$. Thus $t_{\text {count }}>t_{\text {table }}$ then the hypothesis of $\mathrm{Ha}$ is accepted. It concluded that there is an improvement in students' chemistry learning outcomes on salt hydrolysis subject that used e-learning media with problem based learning models. Not only the percentage increased in learning outcomes of $68.4 \%$, but also the percentage of student learning activities of $84 \%$ which means very active.
\end{abstract}

Keywords:

e-learning; learning activities; learning outcomes; problem based learning

\section{Introduction}

The impact of era globalization has carried positive impact of technology information on the world of education. The advantages are located in the speed factor to get information and multimedia facilities that can make learning more interesting, visual, and interactive (Saud, 2009). Ironically, the teacher still uses very little technology media as a learning media, because teacher understands that the teacher operates the computer, resulting in a sense of intimacy in a teacher to invite students to use internet media. Even though researchers saw the benefit of using technology in learning (Daryanto, 2016). Application of technology for educational purposes has broad benefits. Educational technology makes teaching activities to be more productive, scientific, individualized, powerful, immediacy, in line with demands of science and technology (Danim, 2008).

This time learning needs to be supported by technology-based learning media. One of it media that can be used as a support for existing media is form of e-learning. The name e-learning brings the

\footnotetext{
* Corresponding author.

nisahumairah88@gmail.com

doi: https://doi.org/10.2 4114/jpkim.v10i3.12702
}

influence of the process transforming conventional education into digital form, both the content and the system (Dadari \& Dian, 2012). The use of elearning technology to support the learning process, especially for senior high/ vocational schools, is a very important requirement. This makes it easy for each student to be able to recall lessons and provide various information that supports the lesson (Kosasi, 2015; Silaban, 2017; Manalu et al. 2016).

According to Munir (2008), the success of using e-learning media depends on the accuracy of choosing an approach in learning that is applying learning approaches that are centered on students. This approach makes students active in the learning process and explore subject matter. One student-centered learning model is the Problem Based Learning (PBL) model.

Based on research by Juniar et al. (2013), that the improvement of student learning outcomes through the application of weblog-based elearning with the cooperative model of TPS type is higher than the increase in learning outcomes of students who are given teaching without weblogbased e-learning with cooperative TPS type models; Na'imah et al. (2015), in a study entitled Application of Project-Based Learning Assisted by 
E-learning To Improve Student Learning Outcomes contribute to improving student learning outcomes by $12.60 \%$. Furthermore, research conducted by Rahman et al. (2014), that the results of the study indicate that there is a moderate influence on the use of website-based learning media on students' cognitive learning outcomes; Hanum's research (2013) states that overall it can be concluded that the implementation of e-learning learning as a learning media at the Sandhy Putra Telkom Vocational School Purwokerto is effective with a tendency of $77.27 \%$.

Furthermore, based on the results of research by Wasonowati et al. (2014), shows that; Student activities with PBL models are categorized as good with an average of 82.71 and an achievement percentage of $81.25 \%$ and student learning outcomes in the realm of knowledge, attitudes, and skills of students with PBL models are categorized well with the percentage of students achieving the 2013 curriculum core competencies respectively $78 \%, 81.24 \%$ and $78.13 \%$; and Bachtiar (2013), stated that the results of the study were very effective in applying e-learning based problem-based learning models to improve science process skills in physics education students in astronomy courses.

Based on research conducted by Ayyildiz \& Leman (2017), show that PBL is an effective active learning approach that enhances achievement and prevents the formation of alternative conceptions, conceptual difficulties and lack of knowledge among llth-grade students with respect to enthalpy changes in systems; Aidoo et al. (2016), show that the results PBL is an effective way for to teach chemistry so as to improve students' critical thinking and problem solving skills. Accordingly, this study aims to examine the effects of PBL applications with e-learning media on activities and learning outcomes high school students' of salt hydrolysis subject.

\section{Materials and Methods}

The study was conducted in the State Islamic Middle School Binjai. The research steps include elearning media preparation for the topic of salt hydrolysis, validation learning media, and the implementation of e-learning media with Problem Based Learning models to improve learning outcomes and activities student.

The sample were purposively selected from the State Islamic Middle School Binjai consisting of one group, named as experimental class. The sample was made homogenous and normality based on student ability to solve chemistry problem in the pre-test. Samples were all treated equally with total 35 students were included in the data analysis.

This study used instrument test and instrument non-test. Instrument tests were in the form of objective tests (multiple choice questions) and non-test instruments in the form of student activity observation sheets. The test instrument used was a test of students' chemistry learning outcomes namely pretest and posttest. Pretest is given to the sample before treatment with the aim of knowing the similarity of the characteristics of the students' initial abilities. Posttest is given after completion of the treatment process with the aim of knowing student learning outcomes. Test items are designed to cover four cognitive regions according to Bloom's taxonomy, namely aspects of knowledge $(\mathrm{Cl})$, understanding $(\mathrm{C} 2)$, application (C3), and analysis (C4). The number of questions used were 20 items that were validated by the expert validator and tested first.

The non-test instrument used in this study is the observation sheet assessment of student activities. The observation sheet evaluating student attitudes and skills is used to measure student activity during the learning process. Values related to student activity are measured and observed directly by the observer / observer. For the validity of non-test instruments the analysis of the instrument is carried out qualitatively by an expert judgment that considers and analyzes the conformity criteria of the observation sheet, which measures the attitudes measured by attitude indicators and descriptors made by the researcher. This research procedure consists of three stages, namely the preparation stage, the implementation phase and the data processing stage.

\section{Stage of research preparation}

Conduct preliminary observations to school to find out the problems that occur in the learning process, especially in class $\mathrm{XI} \mathrm{MIA}$ about chemistry lessons. Perform content validity on multiple choice test instruments and non-test instruments in the form of observation sheets assessing student attitudes with expert validators. Conducting test instruments on students of class XII MIA in MAN Binjai to determine the distinguishing power, distractor, level of difficulty, validity and reliability of the questions to be given to students as the research sample. Consultation with chemistry teacher in class XI MIA. Prepare the necessary learning tools such as syllabus, 
lesson plans, learning media, and compile student learning evaluations.

\section{Stage of research implementation}

At this stage, first determine one class that will be the experimental sample group. Before learning begins, a pretest is performed to measure student learning achievement before treatment. Give treatment $(X)$ in the experimental class in the form of teaching with PBL learning models using e-learning media. During the research process, observing the activities of students through an observation sheet assesses the attitude of students observed by the observer when learning is taking place, from the beginning to the end of learning. After the treatment process in the class is complete, the next stage provides a posttest to measure student learning outcomes in the class.

\section{Stage of data processing}

The data on the pretest and posttest values were collected and then calculated the difference in the value of student learning outcomes obtained in the experimental class. Conduct test requirements for statistical analysis, namely normality test and data homogeneity test. Calculating the average change in either the increase or decrease in the value of learning outcomes obtained in each class. Applying a statistical test is the two-party t-test to test whether there is an effect of application (X) on improving student learning outcomes. Tabulate the value of the attitude of student activities at each meeting. Calculate the average (mean) of the value of student learning activities and change the value in the form of percent of student learning activities. Comparing percent of student learning activities with student activeness criteria. Draw research conclusions.

\section{Results}

\section{Learning outcomes with e-learning media}

The pre-test was conducted in the experimental class before teaching and learning activities began. Students 'achievements in the pre-test are presented in Table 1. Students' achievements in the experimental class are almost the same for all samples. The results show that students do not fully understand the topic of salt hydrolysis and they are ready to engage in different teaching and learning activities related to the topic of salt hydrolysis. Electronic material is distributed to students in the experimental class. They were also given instructions to use e-learning learning media based on the guidelines provided. During the learning process students are taught to use the problem based learning (PBL) model and use the prepared media. After completing the learning session, students were given a posttest to measure their achievements on the topic of salt hydrolysis as summarized in Table 1.

Table 1

Summary of descriptive statistics of student learning outcomes

\begin{tabular}{lccclcl}
\hline & $\mathrm{N}$ & \multicolumn{1}{c}{ Min } & Max & Mean & \multicolumn{1}{c}{ Stdv } & Varians \\
\hline Pretest & 35 & 36.36 & 63.64 & 51.16 & 5.86 & 34.38 \\
Posttest & 35 & 72.72 & 95.45 & 84.54 & 5.53 & 30.63 \\
Gain (d) & 35 & 18.17 & 45.45 & 33.37 & 6.69 & 44.81 \\
\hline
\end{tabular}

Analysis of learning outcomes data in this study the experimental class taught using PBL learning models with e-learning media before being given treatment obtained that the average value of student learning outcomes is 51.16 and after learning using PBL learning models with elearning media obtained the average student learning outcomes value of 84.54. So that the gain in the experimental class is 33.38. It can be described the difference in the results of the average value of the pretest, posttest and gain (d) experimental class through the diagram on Fig 1 .

Hypothesis testing uses the Dependent sample t-Test with a significant level of $\alpha=0.05$ and a 95\% confidence level in the Microsoft Excel 2013 program. The results of the analysis of hypothesis testing can be seen in Table 2 .

Based on Table 2 shows that the price of $t_{\text {table }}=$ 2.0315 and $t_{\text {count }}=29.5$ in the two-part t-test with $a=0.05$, because $t_{\text {count }}>t_{\text {table }}$ then Ho is rejected and $\mathrm{Ha}$ is accepted. This shows that there is an influence of the application of e-learning media to the Problem Based Learning model to improve student learning outcomes on the topic of salt hydrolysis. Improved student learning outcomes were calculated using the average pretest and posttest values of the experimental class in the study. Based on the calculation of \% gain, it is obtained: Increased learning outcomes for the experimental class is $68.4 \%$. Based on the $\%$ gain criteria this increase indicates that it belongs to the medium category because the value is between $30 \%-70 \%$.

Table 2

Hypothesis test results of student learning outcomes

\begin{tabular}{lccc}
\hline Learning outcomes & $\mathrm{t}_{\text {count }}$ & $\mathrm{T}_{\text {table }}$ & $\alpha$ \\
\hline Experiment & 29.50 & 2.03 & 0,05 \\
\hline
\end{tabular}




\section{Learning activities of student}

Assessment of student learning activities is carried out when giving treatment at each meeting. Based on the results of calculations obtained statistical data on student learning activities in the experimental class which are summarized in the table descriptive statistics of students' learning activities in the experimental class in Table 3 . Based on the Table 3 of activeness criteria, it can be seen that the effect of applying e-learning media to the Problem Based Learning model to student learning activities in topic salt hydrolysis shows that student activity is very active with a percentage of activity of $84 \%$.

Table 3

Summary of descriptive statistics of student learning activities

\begin{tabular}{lcccc}
\hline Learning Activities (\%) & $\mathrm{N}$ & Min & Max & Mean \\
\hline Meeting I & 35 & 56 & 94 & 82.9 \\
Meeting I1 & 35 & 72 & 94 & 85.3 \\
Average meeting 1 \& I1 & 35 & 67 & 94 & 84.1 \\
\hline
\end{tabular}

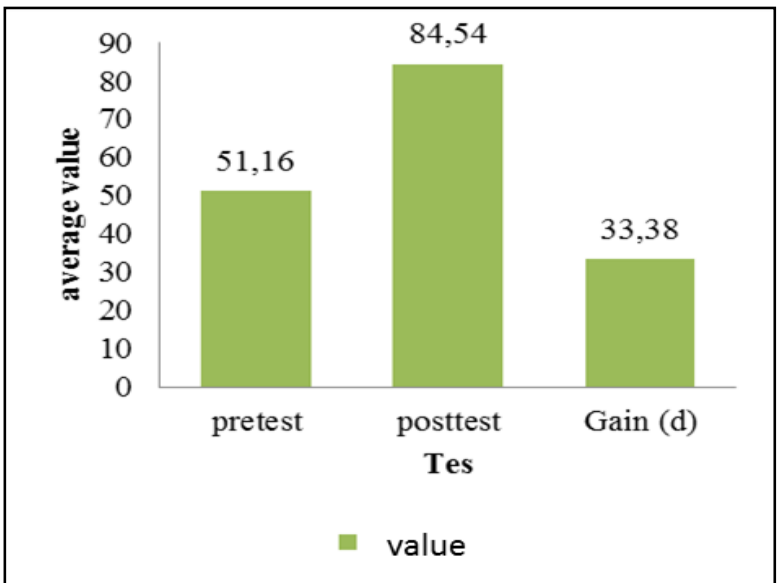

Fig 1 . The difference in the results of the average value of the pretest, posttest and gain.

\section{Discussion}

Based on the results of data analysis with the two-party hypothesis test using the Dependent test, the T-test sample with a significant level of $\alpha$ $=0.05$ and $95 \%$ confidence level in the Microsoft Excel program obtained a t-count of 29.5. Then the null hypothesis $(\mathrm{Ho})$ is rejected and the hypothesis $\mathrm{Ha}$ is accepted, which means there is an increase in student learning outcomes after being given the treatment of Problem Based Learning learning models using e-learning media on the topic of salt hydrolysis, with a percent increase in learning outcomes by $68.4 \%$. This is in line with the research conducted by Na'imah et al. (2015), in a study entitled Application of Project-
Based Learning Assisted by E-learning To Improve Student Learning Outcomes contribute to improving student learning outcomes by $12.60 \%$. Furthermore, supported by research conducted by Rahman et al. (2014), states that the results of the study indicate that there is a moderate influence on the use of website-based learning media on students' cognitive learning outcomes. And research conducted by Juniar et al. (2013), that the increase in student learning outcomes through the application of weblog-based e-learning with the cooperative model of TPS is higher than the increase in learning outcomes of students given teaching without weblog-based e-learning with a cooperative type TPS model.

In the assessment of observations of student learning activities, based on the average calculation obtained by students in meeting $l$ and meeting $\mathrm{ll}$, the average value of student learning activities was obtained by $84 \%$. Based on students' active criteria, student learning activities are classified as very active criteria. So that students learning using PBL models with e-learning media can make students active in the learning process with a percentage of $84 \%$ activeness. This is in line with research conducted by Antrakusuma et al. (2015), which states that e-learning assisted learning can improve student learning activities. Also supported by Utami's research (2016), entitled E-Learning Implementation to Improve Student Learning Activities stated that there is an increase in student learning activities. As well as research conducted by Wasonowati et al. (2014), shows that; Student activities with PBL models are categorized as good with an average of 82.71 and an achievement percentage of $81.25 \%$.

This is evident when the research takes place students are very enthusiastic in following the learning process by asking various questions that they do not know, but this appears gradually and respect that is shown when other students give opinions. PBL learning model uses website-based e-learning media designed to help students understand chemistry subject matter, develop the ability to think, solve problems and foster activity in learning using the help of learning websites provided by researchers.

In PBL learning models students are required to analyze problems that are activities of the scientific method of observing, identifying what they know from the problem is an activity to ask questions and collaborate in solving problems, namely the stages of collecting data and associating to find solutions to the problems they face. The last stage is presenting the results of the 
discussion in front of the class. To solve problems that have been determined by students in groups, students will try to explore/ collect information/ theory/ concepts/ principles from e-learning media that has been provided. So that by implementing the PBL learning model using e-learning media based on this website can improve learning outcomes and can make students active in teaching and learning activities (Panggabean \& Silaban, 2015; Nasution et al 2018; Harahap et al. 2018; Manalu et al. 2018).

\section{Conclusion}

Based on data analysis can be concluded as follows: (1) There is an increase in the chemistry learning outcomes of students in the hydrolysis of salt material learned using e-learning media with the Problem Based Learning model with an increase in learning outcomes by $68.4 \%$. (2) Student learning activities in the salt hydrolysis material learned using e-learning media with the Problem Based Learning model include very active criteria with a percentage of student activity of $84.1 \%$.

\section{Acknowledgments}

The author would like to express the gratefulness to the Principal, Deputy Principal, Administrative Staff, Chemistry Teacher, and all students of State Islamic Middle School Binjai who have helped the author during the research process.

\section{References}

Aidoo, B., Boateng, S. K., Kissi, P. S., \& Ofori, I. (2016). Effect of Problem-Based Learning on Students' Achievement in Chemistry. Journal of Education and Practice, 7(33), 103-108.

Ayyildiz, Y., \& Tarhan, L. (2018). Problem-based learning in teaching chemistry: enthalpy changes in systems. Research in Science \& Technological Education, 36(1), 35-54.

Bachtiar, R.W. (2013). Pengembangan Model Pembelajaran Promblem Based Learning Berbasis E-Learning Untuk Meningkatkan Keterampilan Proses Sains Mahasiswa Pendidikan Fisika Pada Mata Kuliah Astronomi. Jurnal Saintifika, 15(2): 141-149.

Dadari, D.W., \& Dian, N. (2012). Analisis Tes Belajar Siswa Melalui Media Pembelajaran Blog Pada Materi Alkana, Alkena, dan Alkuna. Unesa Journal of Chemical Education, 1(1): 70-75.

Danim, S. (2008). Media Komunikasi Pendidikan. Bumi Aksara: Jakarta.
Daryanto. (2016). Media Pembelajaran Peranannya Sangat Penting Dalam Mencapai Tujuan Pembelajaran. Gava Media: Yogyakarta.

Hanum, N. S. (2013). Keefektifan E-Learning Sebagai Media Pembelajaran (Studi Evaluasi Model Pembelajaran E-Learning SMK Telkom Sandhy Putra Purwokerto). Jurnal Pendidikan Vokasi, 3(1): 90-102.

Harahap, N.M., Hutabarat, W., \& Silaban, S. (2018). The effect of model problem based learning (pbl) assistance of prezi media on student learning outcomes in colloid materials. Advances in Social Science, Education and Humanities Research, 200, 456-458

Juniar, A., Nurjannah., \& Hafni, N. (2013). Pengaruh Media E-learning Berbasis Weblog Dengan Model Pembelajaran Kooperatif Tipe TPS Terhadap Hasil Belajar Kimia Pada Pokok Bahasan Termokimia. Jurnal Penelitian Bidang Pendidikan, 19(1): 44-51.

Kosasi, S. (2015). Perancangan E-Learning untuk Meningkatkan Motivasi Belajar Guru dan Siswa. Prosiding Seminar Nasional Pendidikan Teknik Informatika: 82-88.

Manalu, E., Silaban, S., Silaban, R., \& Hutabarat, W. (2016). The development of chemical practice guidebook colloid system-based integrated contextual character values. Jurnal Pendidikan Kimia, 8(2), 87-89.

Manalu, H.C., Silaban, S., \& Hutabarat, W. (2018). The development of teaching materials stoichiometric integrated multimedia easy sketch. Advances in Social Science, Education and Humanities Research, 200, 352-356.

Munir, M.l.T. (2008). Kurikulum Berbasis Teknologi Informasi dan Komunikasi. Alfabeta: Bandung.

Na'imah, N.J., Supartono., \& Sri, W. (2015). Penerapan Pembelajaran Berbasis Proyek Berbantuan E-learning Untuk Meningkatkan Hasil Belajar Siswa. Jurnal Inovasi Pendidikan Kimia, 9(2): 1566-1574.

Nasution, R., Silaban, S., \& Sudrajat, A. (2018). The influence of problem based learning, guided inquiry learning models assited by lectora inspire, and scientific attitudes to student's cognitive values. Advances in Social Science, Education and Humanities Research, 200, 265269.

Panggabean, F.T.M., \& Silaban, S. (2015). Pengaruh penggunaan media animasi komputer dan motivasi belajar dalam pembelajaran reaksi redoks dan elektrokimia terhadap prestasi belajar mahasiswa. Jurnal Pendidikan Kimia, $7(1)$. 
Rahman, S., Wahid, M., \& Ega, T.B. (2014). Pemanfaatan Media Pembelajaran Berbasis Website Pada Proses Pembelajaran Produktif Di SMK. Jurnal of Mechanical Engineering Education, 1(1): 137-145.

Sa'ud, U.S. (2009). Inovasi Pendidikan. Alfabeta: Bandung.

Silaban, S. (2017). Dasar-dasar pedidikan matematika dan ilmu pengetahuan alam. Medan: Harapan Cerdas Publisher.

Utami, I.S. (2016). Implementasi E-Learning untuk Meningkatkan Aktivitas Belajar Siswa. Jurnal Komputer Terapan, 2(2): 169-178.

Wasonowati, R.R.T., Tri, R., \& Sri, R.D.A. (2014). Penerapan Model Problem Based Learning (PBL) Pada Pembelajaran Hukum - Hukum Dasar Kimia Ditinjau Dari Aktivitas Dan Hasil Belajar Siswa Kelas X IPA SMA Negeri 2 Surakarta Tahun Pelajaran 2013/2014. Jurnal Pendidikan Kimia (JPK), 3(3): 66-75. 